\title{
ANALISIS PENDAPATAN TENAGA KERJA SEKTOR PERTANIAN PADA IFLS 5
}

\author{
Damar Jati ${ }^{1}$, Rifki Khoirudin ${ }^{2} *$ \\ ${ }^{1}$ Universitas Ahmad Dahlan \\ * Email: rifki.khoirudin@ep.uad.ac.id
}

\begin{abstract}
This research was conducted with the aim to be able to find out the factors that affect the income of agricultural sector workers based on data from Indonesian family life survey wave 5 (IFLS 5) in 2014. Based on existing problems, namely the high absorption of labor in the agricultural sector but ironically the agricultural sector has the lowest level of income is from other sectors. For this reason, the writer conducts research with the title (Analysis of Factors Affecting the Income Level of Indonesian Agricultural Sector Workers). This study took a sample of 1104 respondents from the total population of the agricultural sector as much as 1891 . Respondents were filtered based on productive age 15-65 years. With the dependent variable income of workers and the independent variables of education level, age, gender, working hours, marital status and work experience. From the results of the statistical tests conducted shows that $51 \%$ of the independent variables affect the independent variables and the rest are influenced by independent variables outside the research model. From the results of multiple linear regression tests indicate that the independent variables significantly influence the variables of education level, age, working hours, and work experience and can explain their influence on the labor sector income variable in Indonesia.
\end{abstract}

Keywords: IFLS 5, Labor, Income

\section{PENDAHULUAN}

Negara berkembang seperti Indonesia, memiliki permasalahan ketenagakerjaan yang sangat penting, diperlukan sebuah pemahaman baru terhadap situasi ketenagakerjaan, bahwa masalahnya bukanlah hanya orang tidak bekerja atau bekerja, melainkan kesejahteraan pekerja yang dapat dilihat dari tingkat pendapatan yang mereka dapatkan (Priyono, 2002). Di mana tingkat pendapatan akan menentukan taraf hidup seseorang, selanjutnya taraf hidup yang buruk akan berdampak pada tingkat keterbelakangan dan kemiskinan seseorang.

Data dari BPS (2013) menunjukkan bahwa 11,4 persen penduduk Indonesia berada di bawah garis kemiskinan nasional. Meskipun jumlah masyarakat miskin terus berkurang tahun-tahun selanjutnya, namun secara keseluruhan ketimpangan berdasarkan ukuran indeks gini mengalami peningkatan dan mencapai puncaknya tahun 2015 yaitu sebesar 0,41 . Hal tersebut menunjukkan ketimpangan persebaran pendapatan yang semakin melebar. Sektor Pertanian selalu di atas dari sektor lain dalam jumlah pekerjanya. Berdasarkan data BPS tahun 2014 pertanian memiliki 38.973.033 orang pekerja pada tahun 2014. Ini membuat ratarata pendapatan tenaga kerja sektor ini di Indonesia masih rendah. Pendapatan tenaga kerja di sektor pertanian paling rendah dari sembilan sektor yang ada menjadi hal yang mencolok namun sangat menarik untuk di teliti lebih jauh lagi, mengingat sektor pertanian merupakan sektor yang paling banyak dalam menyerap tenaga kerja di Indonesia, sehingga diperkirakan dapat mempengaruhi kesejahteraan dari setiap tenaga kerja yang terlibat. 
Seseorang dapat meningkatkan penghasilannya melalui investasi dalam pendidikan. Orang yang memiliki tingkat pendidikan lebih tinggi akan memperoleh pendapatan yang lebih baik. Setiap tambahan satu tahun sekolah berarti di satu pihak meningkatkan kemampuan kerja dan tingkat penghasilan seseorang, akan tetapi di pihak lain menunda penerimaan penghasilan selama satu tahun dalam mengikuti sekolah tersebut. Selain tingkat pendidikan, pendapatan juga dipengaruhi oleh pengalaman kerja. Seseorang yang baru mulai bekerja kurang berpengalaman dan biasanya memiliki produktivitas yang rendah pula. Semakin lama pengalaman kerja yang dimiliki tenaga kerja mengindikasikan semakin meningkat kemampuan tenaga kerja sehingga pendapatan pun meningkat. Adanya perbedaan jenis kelamin dapat mempengaruhi tingkat produktivitas seseorang. Secara universal, tingkat produktivitas laki-laki lebih tinggi dari perempuan. Hal tersebut dipengaruhi oleh faktorfaktor yang dimiliki oleh perempuan seperti fisik yang kurang kuat, dalam bekerja cenderung menggunakan perasaan atau faktor biologis seperti harus cuti ketika melahirkan. Sehingga perbedaan jenis kelamin juga mempengaruhi tingkat pendapatan yang diterima seseorang.

Perbedaan jam kerja dapat mempengaruhi pendapatan yang diperoleh. Seseorang yang lebih banyak mencurahkan waktu untuk bekerja akan memperoleh pendapatan yang lebih tinggi dibandingkan dengan tenaga kerja yang sedikit mencurahkan waktunya untuk bekerja. Selain itu, perbedaan tingkat penerimaan pendapatan tenaga kerja sektor pertanian juga dipengaruhi oleh status pernikahan mereka dalam bekerja baik sudah menikah atau sendiri. Untuk menggambarkan pengaruh variabel independen terhadap variabel dependen dalam penelitian ini dikemukakan suatu model paradigma penelitian.

\section{KAJIAN LITERATUR}

Menurut BPS (2015), pendapatan adalah biaya yang diterima dari layanan dalam bentuk uang atau barang, dibayar oleh perusahaan/kantor/majikan. Hadiah dalam bentuk barang dinilai dengan harga lokal. Penghasilan dalam ekonomi adalah hasilnya, baik dalam bentuk uang maupun penggunaan kekayaan lainnya (layanan manusia). Pendapat lain menunjukkan bahwa pendapatan adalah hasil dari penjualan faktor-faktor produksi yang dimilikinya ke sektor produksi. Menurut Djojohadikusumo Sumitro (1990: 25), dari segi ekonomi, pendapatan itu adalah nilai maksimal yang dapat dikonsumsi seseorang dalam suatu periode dengan mengharapkan adanya situasi yang sama di akhir periode tersebut seperti keadaan semula. Berdasarkan pendapat para ahli di atas, dapat disimpulkan bahwa pendapatan adalah hadiah, baik yang diterima dalam bentuk uang maupun penggunaan kekayaan lainnya (layanan manusia) dan nilai maksimal yang dapat dikonsumsi seseorang selama periode kerja.

Pertanian adalah serangkaian proses produksi alami yang didasarkan pada proses pertumbuhan tanaman dan hewan. Kegiatan produksi di setiap peternakan adalah bagian dari perusahaan, dengan biaya dan pendapatan menjadi penting. Tumbuhan adalah tanaman pertanian terpenting. Ini menyerap gas karbon dioksida dari udara melalui daunnya. Air yang terserap dan nutrisi kimia dari tanah melalui akar. Dari bahan-bahan ini, dan kemudian menggunakan sinar matahari, itu membuat biji, buah, serat dan minyak yang dapat digunakan oleh manusia. Pertumbuhan tanaman dan hewan liar terjadi di alam tanpa campur tangan manusia. Ribuan tanaman di berbagai belahan dunia telah berevolusi seiring waktu sebagai reaksi terhadap perbedaan radiasi matahari, suhu, jumlah air atau kelembaban yang tersedia dan sifat tanah. Setiap jenis tanaman membutuhkan kondisinya sendiri, terutama pada musim-musim tertentu atau sering disebut musim. Tumbuhan yang tumbuh di suatu daerah juga menentukan spesies hewan mana yang hidup di daerah itu, karena beberapa dari mereka memakan tanaman di daerah itu, sementara yang lain memakan hewan lain. 
Akibatnya, ada kombinasi tanaman dan hewan di berbagai belahan dunia. Sektor pertanian adalah bagian dari 9 sektor yang digunakan sebagai indikator BPS dalam perhitungan output. BPS membagi sektor pertanian ke dalam beberapa sub sektor yang lebih spesifik yang terdiri atas 6 (enam) sub sektor, yaitu: tanaman pangan, tanaman hortikultura, tanaman perkebunan, peternakan, perikanan, dan kehutanan. Untuk perikanan dibagi lagi menjadi perikanan budidaya dan perikanan tangkap. Dari 6 sub sektor tersebut data dikumpulkan dan diolah oleh BPS yang kemudian di publikasikan sebagai acuan gambaran kondisi dan pengambilan keputusan.

Pendidikan adalah upaya yang secara sadar dan sengaja dilakukan untuk mengubah perilaku manusia, baik secara individu maupun kelompok untuk membantu orang tumbuh melalui pendidikan dan pelatihan. Hubungan antara tingkat pendidikan dan pendapatan bahwa pendidikan adalah salah satu modal potensial orang, di mana pendidikan akan ada ketika diterapkan pada kehidupan nyata, termasuk pekerjaan. Tingkat pendidikan memengaruhi pemilihan pekerjaan. Semakin tinggi tingkat pendidikan yang dimiliki seseorang, semakin besar keinginan untuk pergi bekerja dengan tingkat tantangan yang tinggi. Harapan dan ide kreatif akan ditetapkan dalam upaya untuk menyelesaikan tugas yang sempurna. Ide kreatif adalah simbol realisasi diri dan berbeda dari yang lain dalam menyelesaikan tugas dan kualitas hasil.

Jenis kelamin adalah perbedaan antara wanita dan pria secara biologis sejak seseorang dilahirkan." Jenis kelamin berhubungan dengan tubuh pria dan wanita, di mana pria menghasilkan sperma, sementara wanita menghasilkan telur dan secara biologis mampu menstruasi, kehamilan dan menyusui Perbedaan biologis dan fungsi biologis baik pria dan wanita tidak dapat ditukar antara keduanya. "Sementara secara etimologis, jenis kelamin memiliki arti sebagai perbedaan dalam gender yang diciptakan oleh seseorang sendiri melalui proses sosial budaya yang panjang. Perbedaan perilaku antara pria dan wanita tidak hanya disebabkan oleh faktor biologis, tetapi juga disebabkan oleh faktor proses sosial dan budaya. Karena itu gender dapat berubah dari waktu ke waktu, dari waktu ke waktu, bahkan di antara kelas sosial-ekonomi masyarakat.

Usia adalah satuan waktu yang biasa digunakan untuk mengukur waktu keberadaan suatu benda atau makhluk, baik yang hidup maupun yang mati yang ada di dunia. Sebagai contoh, usia seseorang dikatakan telah diukur selama lima belas tahun dari saat ia dilahirkan hingga saat usia itu dihitung. Itu sebabnya usia diukur dari tanggal lahir, sehingga tanggalnya (sekarang). Selain itu, usia juga diukur dari tanggal kejadian, dimulai dengan tanggal (sekarang).

Jam kerja adalah bagian dari empat faktor organisasi yang berpotensi menjadi sumber stres bagi karyawan di tempat kerja (Robbins, 2006: 796). Davis dan Newstrom mengungkapkan (dalam Imatama, 2006: 4) bahwa ada beberapa karakteristik pekerjaan dan lingkungan kerja yang mengandung tekanan kerja, termasuk keterbatasan waktu untuk bekerja. Jam kerja "normal" umumnya diartikan sebagai hari kerja dan jam yang tersisa untuk rekreasi dan istirahat. Istirahat adalah aktivitas di malam hari, sementara bekerja adalah aktivitas di siang hari. Ini terkait dengan mereka yang bekerja dengan jadwal yang tidak biasa, baik dalam layanan kerja dan dengan jam kerja yang diperpanjang hingga siang hari, bekerja di malam hari dan bekerja selama pola tidur.

Perkawinan menurut istilah bahasa Indonesia, perkawinan berasal dari kata "kawin" yang menurut bahasa berarti membentuk keluarga dengan lawan jenis; berhubungan seks atau hubungan seksual. Pernikahan juga disebut 'perkawinan', yang berasal dari kata 'perkawinan', yang menurut bahasa berarti mengumpulkan, saling memberi masukan dan digunakan untuk makna hubungan seksual. Untuk memahami perkawinan menurut Undang-Undang Nomor 1 Tahun 1974 tentang perkawinan yang disebutkan dalam Pasal 1 berbunyi: "Perkawinan 
adalah ikatan kelahiran dan jiwa antara lelaki dan perempuan sebagai suami-istri dengan tujuan membentuk keluarga (rumah tangga), bahagia dan selamanya berdasarkan pada agama dan Satu Dewa ". Menurut kumpulan hukum Islam, gagasan perkawinan dalam Pasal 2 menyatakan bahwa "Perkawinan menurut hukum Islam adalah perkawinan, yang merupakan kontrak yang sangat kuat atau Mitsaqan Ghalizhan untuk mematuhi perintah-perintah Allah dan melaksanakannya sebagai ibadah".

Pengalaman kerja adalah proses pembentukan pengetahuan dan keterampilan tentang langkah-langkah pekerjaan karena keterlibatan karyawan dalam pelaksanaan tugas kerja (Manulang, 1984: 15). Pengalaman kerja adalah ukuran seberapa lama waktu atau periode pekerjaan yang dilakukan seseorang dapat memahami tugas-tugas pekerjaan dan telah melakukannya dengan baik (Ranupandojo, 1984: 71). Pengalaman kerja adalah pengetahuan dan keterampilan yang dikenal dan dikendalikan oleh seseorang yang merupakan hasil dari tindakan atau pekerjaan yang telah dilakukan selama beberapa waktu (Trijoko, 1980: 82).

Berdasarkan alasan tersebut penulis tertarik untuk meneliti lebih jauh tentang faktor apa saja yang mempengaruhi pendapatan para pekerja di sektor pertanian dengan melibatkan beberapa variabel-variabel terkait, di antaranya tingkat pendidikan tenaga kerja, jenis kelamin, usia, jam kerja, status pernikahan, dan pengalaman kerja dengan judul penelitian "Analisis faktor-faktor yang mempengaruhi tingkat pendapatan tenaga kerja sektor pertanian di Indonesia (IFLS 5)".

Penelitian ini digunakan untuk melihat hubungan beberapa variabel terhadap satu variabel terikat. Model kerangka peikiran penelitian ini dapat digambarkan sebagai berikut:

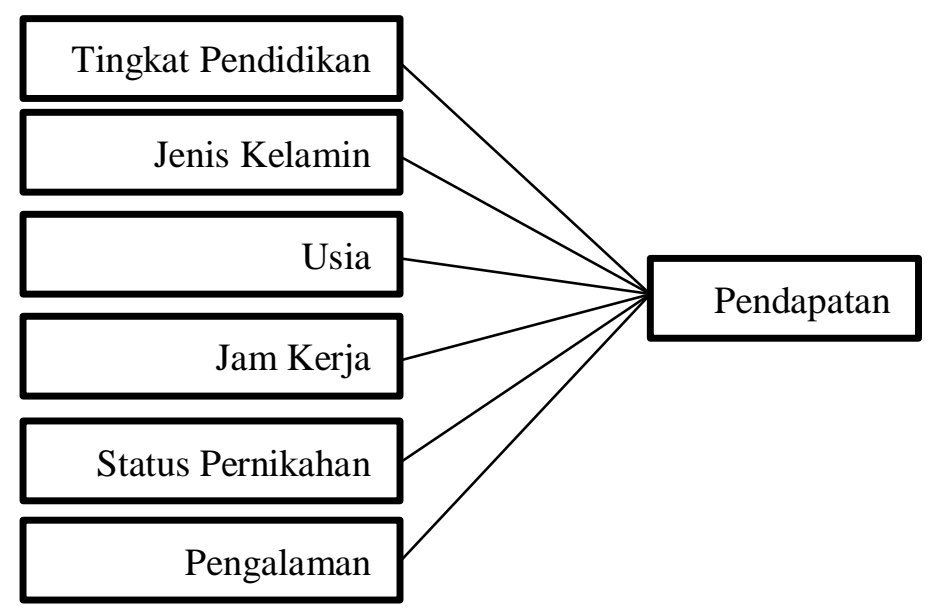

Gambar 1. Kerangka Berpikir

Sumber : Data diolah, 2020

Variabel-variabel yang digunakan dalam penelitian ini adalah variabel dependen dan beberapa variabel independen. Variabel dependen adalah variabel yang nilai-nilainya bergantung pada variabel lainnya, sedangkan variabel independen adalah variabel yang nilai-nilainya tidak bergantung dengan variabel lainnya. Variabel dependen yang digunakan penelitian ini adalah tingkat pendapayan Pendapatan. Sedangkan variabel independen meliputi tingkat pendidikan, jenis kelamin, usia, jam kerja, status pernikahan pekerja, dan pengalaman yang dimiliki pekerja.

\section{METODE PENELITIAN}

Dalam penelitian ini menggunakan variabel tingkat pendidikan serta variabel independen lain yaitu usia, jenis kelamin, jam kerja, status pernikahan, dan pengalaman kerja maka model persamaannya adalah: 
Keterangan :

$$
Y=\beta_{0}+\beta_{1} X_{1}+\beta_{2} X_{2}+\beta_{3} X_{3}+\beta_{4} X_{4}+\beta_{5} X_{5}+\beta_{6} X_{6}+e_{i} \ldots
$$

$Y \quad=$ Pendapatan

$X_{1}=$ Pendidikan dalam 7 jenjang pendidikan

$X_{2} \quad=$ Jenis Kelamin (Laki-laki $=0$, Perempuan $=1$ )

$X_{3}=$ Usia dalam satuan tahun $\backslash$

$X_{4} \quad$ Jam kerja dalam satuan jam

$X_{5}=$ Status pernikahan $($ Belum Menikah $=0$, Menikah $=1)$

$X_{6}=$ Pengalaman kerja dalam satuan tahun

घi $=$ error term

$\beta 1, \beta 2, \beta 3, \beta 4, \beta 5, \beta 6=$ Koefisien

\section{Uji Parsial (uji T)}

Tes parsial digunakan untuk menentukan apakah setiap tingkat variabel pendidikan, jenis kelamin, usia, jam kerja, status pernikahan, dan pengalaman kerja berdampak pada pendapatan. Dasar pengambilan keputusan adalah bahwa hipotesis diterima jika nilai probabilitas tingkat kesalahan $\mathrm{t}$ atau nilai-p lebih kecil dari tingkat signifikansi yang ditentukan (dalam penelitian ini tingkat signifikansi 5\%). Selain itu tingkat signifikan hasil uji juga ditentukan oleh nilai t-hitung > t-tabel. Apabila hasil uji menunjukkan nilai t-hitung lebih besar dari t-tabel maka Ho akan ditolak dan menerima Ha (Gujarati, 2003).

\section{Uji Simultan (uji F)}

Uji simultan (uji statistik F) pada dasarnya menunjukkan apakah semua variabel independen yang digunakan dalam model penelitian mempunyai pengaruh secara bersama-sama terhadap variabel dependen. Uji $\mathrm{F}$ digunakan untuk mengetahui apakah semua variabel tingkat pendidikan, jenis kelamin, usia, jam kerja, status pernikahan, dan pengalaman kerja mempunyai pengaruh secara bersama-sama terhadap pendapatan. Dasar untuk pengambilan keputusan adalah hipotesis akan diterima apabila nilai probabilitas tingkat kesalahan $\mathrm{F}$ atau pvalue lebih kecil dari taraf signifikansi tertentu (taraf signifikansi 5\%) dan nilai dari f-tabel lebih besar dari f-hitung.

\section{Koefisien determinasi (R2)}

Koefisien determinasi (R2) dimaksudkan untuk mengukur seberapa jauh kemampuan model variabel independen untuk menjelaskan variasi variabel dependen. Koefisien determinasi adalah antara nol dan satu. Nilai R2 kecil menunjukkan bahwa kemampuan variabel independen untuk menjelaskan variasi dalam variabel dependen dengan variasi kecil sangat terbatas. Nilai yang mendekati satu berarti bahwa variabel independen menyediakan hampir semua informasi yang diperlukan untuk memprediksi variasi dalam variabel dependen (Imam Ghozali, 2011: 97-99).

\section{Uji Multikolinearitas}

Uji multikolinearitas adalah uji yang dilakukan untuk melihat ada atau tidaknya korelasi yang tinggi antara variabel-variabel bebas dalam suatu model regresi linear berganda. Jika ada korelasi atau hubungan yang tinggi di antara variabel-variabel independennya, maka hubungan antara variabel bebas terhadap variabel terikatnya menjadi terganggu. Sebagai contohnya, adalah model regresi dengan variabel independennya motivasi, kepemimpinan dan kepuasan kerja dengan variabel dependennya adalah kinerja. Pemikiran sederhananya adalah bahwa model tersebut adalah untuk mencari pengaruh antara motivasi, kepemimpinan dan kepuasan kerja terhadap kinerja. Jadi tidak boleh ada hubungan yang tinggi antara 
motivasi dengan kepemimpinan, motivasi dengan kepuasan kerja atau antara kepemimpinan dengan kepuasan kerja. Uji Multikolinearitas apabila nilai standar eror $>1$ berarti menunjukkan adanya multikolinearitas. Hal ini menunjukkan dengan adanya multikolinearitas, nilai kesalahan atau standar error menjadi besar, sehingga nilai Koefisien Beta (B) tidak dapat mengukur variabel terikat secara tepat.

\section{Uji Heteroskedastisitas}

Uji heteroskedastisitas adalah tes yang dilakukan untuk melihat apakah ada ketidaksamaan dalam varian dari satu residu ke observasi lain ke observasi. Model regresi yang memenuhi persyaratan adalah mereka yang memiliki kesamaan dalam varian residual, satu persepsi dalam persepsi lain masih disebut homocedasticity. Deteksi heteroskedastisitas dapat dilakukan dengan memplot metode scatter plot dengan memplot nilai ZPRED (nilai prediktif) dengan SRESID (nilai residual). Model yang dikatakan baik diperoleh jika tidak ada pola spesifik dalam grafik, seperti mengumpulkan di tengah, menyempit dan kemudian melebar atau melebar dari penyempitan. Tes statistik yang dapat digunakan adalah tes Glejser, tes taman, tes putih atau metode Breuch-Pagan. Tes regresi linier harus memiliki sifat homoskedastisitas. Untuk menguji heteroskedastisitas untuk banyak metode, kami menggunakan metode Breusch-Pagan dalam kasus ini. Dalam tes ini dikatakan bahwa tidak ada gejala heteroskedastisitas jika nilai-nilai P ditunjukkan dengan nilai "Prob> chi2"> 0,05.

\section{HASIL DAN PEMBAHASAN}

\section{Uji Normalitas}

Dalam penelitian ini untuk menguji normalitas data menggunakan uji Skewness-Kurtosis (Jarque Bera) berikut hasil uji tersebut:

Tabel 1. Uji Normalitas

\begin{tabular}{llll}
\hline Variabel & Pr(Skewness) & $\operatorname{Pr}($ Kurtosis $)$ & Prob > chi2 \\
\hline Pendapatan & 0,641 & 0,023 & 0,07 \\
\hline
\end{tabular}

Sumber: IFLS 5 diolah

Dengan menggunakan sampel sebanyak 40 responden hasil uji tersebut menunjukkan bahwa data yang digunakan tersidtribusi normal. Hal tersebut dapat di tunjukan dengan nilai Prob chi square $>\alpha$ yaitu probabilitas yang didapat sebesar 0,0751 sedangkan nilai $\alpha$ yang digunakan dalam penelitian ini sebesar $0.05 \%$. berdasarkan uji diatas maka menyimpulkan bahwa data yang digunakan dapat menjadi acuan dalam penelitian ini.

\section{Uji Regressi Berganda}

Untuk menunjukkan hubungan independen variabel terhadap variabel dependen dalam penelitian ini menggunakan uji regresi berikut hasil uji regresi yang telah dilakukan:

Tabel 2. Uji Regresi Berganda

\begin{tabular}{clcccl}
\hline No & Variabel & Koefisien & t-tabel & t-hitung & \multicolumn{1}{c}{ Keterangan } \\
\hline 1 & Pendidikan & $463.242,1$ & 1,96 & 3,69 & Signifikan \\
2 & Jenis Kelamin & 272.5787 & 1,96 & 8,52 & Tidak Signifikan \\
3 & Usia & $33.647,23$ & 1,96 & 2,26 & Signifikan \\
4 & Jam Kerja & $84.754,97$ & 1,96 & 7,62 & Signifikan \\
5 & Status Pernikahan & $841.119,5$ & 1,96 & 2,18 & Tidak Signifikan \\
6 & Pengalaman Kerja & $137.825,6$ & 1,96 & 2,40 & Signifikan \\
7 & Konstanta & $-217.609,3$ & - & - & \\
\hline
\end{tabular}

Sumber: Olah data, 2020 
Dari hasil uji tersebut dapat digambarkan dengan model ekonomi sebagai berikut: $Y=-217609.3+463242.1 X_{1}+2725787 X_{2}+33647.23 X_{3}+84754.97 X_{4}+841119.5$

$$
\mathrm{X}_{5}+137825.6 \mathrm{X}_{6} \ldots(2)
$$

Keterangan :

$\mathrm{Y}=$ Pendapatan

$\mathrm{X} 1=$ Pendidikan dalam 7 jenjang pendidikan

$\mathrm{X} 2=$ Jenis Kelamin $($ Laki-laki $=0$, Perempuan $=1)$

$\mathrm{X} 3=$ Usia dalam satuan tahun

X4 = Jam kerja dalam satuan jam

X5 = Status pernikahan (Belum Menikah $=0$, Menikah=1)

X6 = Pengalaman kerja dalam satuan tahun

\section{Uji Parsial t}

Dari uji tersebut menunjukkan hasil bahwa variabel Pendidikan signifikan mempengaruhi pendapatan tenaga kerja sektor pertanian, di tunjukan dengan nilai p-value $0.000<\alpha 5 \%$ dan t-hitung 3,69>t-tabel 1,96. Berikutnya variabel jenis kelamin tidak signifikan mempengaruhi pendapatan tenaga kerja sektor pertanian, walaupun di tunjukan dengan nilai p-value $0.000<$ a 5\% dan t-hitung 8,52 > t-tabel 1,96 akan tetapi konstanta bernilai negatif yang membuat variabel dummy atau 2 sisi menjadi dikatakan tidak signifikan. Berikutnya variabel Usia signifikan mempengaruhi pendapatan tenaga kerja sektor pertanian, di tunjukan degan nilai pvalue $0.024<\alpha 5 \%$ dan t-hitung 2,26 $>$ t-tabel 1,96. Berikutnya variabel Jam kerja signifikan mempengaruhi pendapatan tenaga kerja sektor pertanian, di tunjukan degan nilai p-value $0.000<\alpha 5 \%$ dan t-hitung 7,62 > t-tabel 1,96. Berikutnya variabel Status pernikahan tidak signifikan mempengaruhi pendapatan tenaga kerja sektor pertanian, walaupun di tunjukan degan nilai p-value $0.030<\alpha 5 \%$ akan tetapi konstanta bernilai negatif yang membuat variabel dummy atau 2 sisi menjadi dikatakan tidak signifikan. Dan yang terakhir variabel Pengalaman kerja signifikan mempengaruhi pendapatan tenaga kerja sektor pertanian, di tunjukan degan nilai p-value $0.017<\alpha 5 \%$. Berdasarkan uji t menunjukkan bahwa secara parsial setiap variabel-variabel independen yang dipilih mempengaruhi variabel dependen secara signifikan. Dalam penelitian ini variabel pendidikan, usia, jam kerja, dan pengalaman kerja secara parsial mempengaruhi variabel pendapatan.

\section{Uji Simultan F}

Uji simultan atau uji f dilakukan untuk mengetahui tingkat signifikansi variabel independen secara simultan atau secara bersama-sama dalam mempengaruhi variabel dependen. Berikut hasil uji f dalam penelitian ini:

Tabel 3. Uji Simultan F

\begin{tabular}{ccccc}
\hline F-hitung & F-tabel & Signifikansi & Probabilitas & Keterangan \\
\hline 29,47 & 1,104 & 0,05 & 0.000 & Signifikan \\
\hline
\end{tabular}

Sumber: IFLS 5 diolah

Dari hasil uji f tersebut menunjukkan bahwa nilai $\mathrm{p}$-value $0.000<\alpha$ yang artinya secara simultan variabel-variabel independen mempengaruhi variabel dependen. Dalam penelitian ini menunjukkan bahwa variabel pendidikan, jenis kelamin, usia, jam kerja, status pernikahan, dan pengalaman kerja secara bersama-sama mempengaruhi variabel pendapatan. 


\section{Uji R-square}

Uji R-square digunakan untuk menunjukkan seberapa besar variabel-variabel independen mempengaruhi variabel dependen di luar variabel-variabel bebas lainya yang tidak termasuk ke dalam penelitian ini. Berikut hasil uji R-square penelitian ini:

Tabel 4. Uji R-Squared

\begin{tabular}{ll}
\hline R-Square & 0,5138 \\
\hline Sumber: IFLS 5 diolah &
\end{tabular}

Dari hasil uji R-square menunjukkan bahwa variabel-variabel independen dapat mempengaruhi variabel dependen sebesar 51,38\% yang artinya variabel dependen juga dipengaruhi oleh variabel bebas di luar variabel dependen sebesar 49,62\%. Namun hasil penelitian ini dapat digunakan sebagai acuan dikarenakan dapat memenuhi lebih dari setengah dari komponen yang mempengaruhi variabel dependen.

\section{Uji Multikolinearitas}

Untuk melihat keterkaitan antar variabel independen dalam penelitian ini menggunakan uji multikolinearitas. Metode yang digunakan dalam penelitian ini adalah dengan melihat nilai VIF atau Tolerance. Berikut hasil uji yang dilakukan:

Tabel 5. Uji Multikolinearitas

\begin{tabular}{lcc}
\hline Variabel & VIF & 1/VIF \\
\hline Tingkat Pendidikan & 1,15 & 0,873 \\
Jenis Kelamin & 1,02 & 0,977 \\
Usia & 1,30 & 0,768 \\
Jam Kerja & 1,03 & 0,969 \\
Status Pernikahan & 1,17 & 0,856 \\
Pengalaman Kerja & 1,03 & 0,973 \\
\hline Sumber: IFLS 5 diolah & &
\end{tabular}

Dari hasil uji tersebut menunjukkan bahwa nilai VIF $<10$ atau nilai $1 /$ VIF $>0.1$ yang mengartikan bahwa masing-masing variabel independen tidak memiliki keterkaitan. Sehingga uji ini menyimpulkan bahwa variabel-variabel independen dapat berdiri sendiri dan tidak mengandung multikolinearitas

\section{Uji Heterokedastisitas}

Dalam penelitian ini menggunakan uji Bruch-pagan/cock-weisberg untuk melihat apakah ada ketidaksamaan varian dari residual untuk semua pengamatan. Berikut hasil uji heterokedastisitas yang dilakukan:

Tabel 6. Uji Heterokedastisitas

\begin{tabular}{cc}
\hline Chi2 & 0,02 \\
\hline Prob $>$ chi2 & 0.8913 \\
\hline
\end{tabular}

Sumber: IFLS 5 diolah

Dari hasil uji tersebut menunjukkan bahwa nilai Prob chi square $0.8193>\alpha 5 \%$ yang mengartikan bahwa Ho di tolak dan menyimpulkan bahwa variabel-variabel tersebut tidak mengandung heterokedastisitas. 


\section{KESIMPULAN DAN SARAN}

\section{Kesimpulan}

Dari hasil penelitian ini dapat disimpulkan bahwa pendapatan pekerja di sektor pertanian masih rendah dan dibawah dari sektor lainya. Variabel-variabel dalam penelitian ini juga dapat menunjukkan bahwa pendapatan sangat dipengaruhi oleh faktor demografi penduduk. Faktor demografi akan menunjukkan seberapa besah tingkat pendapatan karena mendesak manusia untuk menambah pendapatan dan berlaku lebih produuktif lagi. Dari hasil penelitian ini dapat disimpulkan bahwa Pendidikan yang tinggi akan mengubah pola pikir pekerja sektor pertanian dan berdampak pada teknik dan skill sehingga meningkatkan pendapatan. jenis kelamin yang didominasi oleh laki-laki memiliki pengaruh besar dimana seorang laki-laki memiliki kemampuan fisik yang lebih bai dari wanita dan dalam kehidupan masyarakat sudah terbentuk sebuah kebiasaan bahwa laki-laki adalah sosok pencari nafkah. Akan tetapi di era modern kedudukan laki-laki dan perempuan sam sehingga peluang untuk memiliki pendapatan lebih pun sama antara laki-laki dan perempuan. Usia seseorang akan mencapai puncak produktif setelah dan kemudian akan berpengaruh negatif ketika kemampuan fisik mulai menurun akibat bertambahnya usia.

Jam kerja berpengaruh positif meningkatkan pendapatan pekerja hal ini disebabkan oleh pembagian waktu luang dan waktu bekerja. Semakin banyak waktu kerja pekerja maka produktifitasnya akan semakin banyak. Sebaliknya apabila semakin bnayak waktu luang pekerja maka sisa waktu untuk bekerjanya semain sedikit pula sehingga produktifitas pun semakin menurun. ketika seseorang melepas masa lajangnya dan memutuskan untuk hidup bersama pasangan berarti akan meningkatkan kebutuhan mereka akan tetapi menigkatkan kebutuhan belum tentu akan meningkatkan pendapatan seseorang melihat seorang yang lajang pu memilkin kebutuhan pula. Seorang pekerja akan selalu menambah skil dan penglaman kerja seiring dengan lama waktunya bekerja. Hal ini dikarenakan dalam proses bekerja akan menemukan masalah-masalah yang di atasi sehingga membentuk sebuah kebiasaan yang memudahkan dalam mengatasi masalah-masalah di pekerjaan selanjutnya.

\section{Saran}

Berdasarkan kesipulan penelitian ini terdapat hal-hal yang dapat digunakan sebagai acuan guna meningkatkan pendapatan pekerja sektor pertanian diantaranya:

1. Meningkatkan skill dan kemampuan pekerja dengan pelatihan pelatihan tentang pertanian sesuai dengan karakteristik lingkungannya.

2. Memberikan kesempatan kepada petani yang berpengalaman untuk dapat berbagi ilmu kepada petani-petani pemula sehingga dapat meratanya ilmu pertanian kepada seluruh pekerja.

3. Memberikan jenjang pendidikan yang mampu di jangkau oleh masyarakat berpendapatan rendah, melihat sektor pertanian di dominasi oleh masyarakat berpendapatan rendah. Jenjang pendidikan yang rendah yang dimaksud adalah SMK pertanian.

\section{REFERENSI}

BPS. (2013). Survei Angkatan Kerja Nasional. Jakarta: Badan Pusat Statistik. BPS. (2014). Survei Angkatan Kerja Nasional. Jakarta: Badan Pusat Statistik. BPS. (2015). Survei Angkatan Kerja Nasional. Jakarta: Badan Pusat Statistik BPS. (2018). Survei Angkatan Kerja Nasional. Jakarta: Badan Pusat Statistik. Djojohadikusumo, Sumitro. (1994). Perkembangan Pemikiran Ekonomi: Dasar Teori Ekonomi Pertumbuhan dan Ekonomi Pembangunan, Jakarta:LP3ES 
Gujarati, Damodar. (2003), Ekonometri Dasar. Terjemahan: Sumarno Zain, Jakarta: Erlangga.

Heni Novita. (2016). Analisis Determinan Pendapatan Tenaga Kerja Sektor Industri Di Indonesia Tahun 2001. Skripsi. Yogyakarta: Universitas Negeri Yogyakarta.

Imam Ghozali. (2011). Aplikasi Analisis Multivariate dengan Program IBM SPSS 19.Semarang: Badan Penerbit Universitas Diponegoro.

Imatama, Zuhrina. (2006). Pengaruh Stres Kerja Terhadap Kinerja Karyawan di Lembaga Perkebunan ( LPP ) Kampus Medan. Medan: Program Strata-1 Jurusan Manajemen Universitas Sumatera Utara. 